\title{
Social Skills and Social Acceptance in Different Educational Levels: A Cross-Sectional Study
}

\section{Daniel Bartholomeu ${ }^{1,2^{*}}$, José Maria Montiel ${ }^{3}$, Gleiber Couto ${ }^{4}$, Cintia Heloína Bueno', Fernanda Helena Soares Garcia ${ }^{1}$, Fernando Pessotto ${ }^{1,2}$}

\author{
${ }^{1}$ Nexo-Institute of Applied Psychology, Americana, Brazil \\ ${ }^{2}$ UNIANCHIETA, Jundiai, Brazil \\ ${ }^{3}$ University Saint Judas, São Paulo, Brazil \\ ${ }^{4}$ Federal University of Goias, Goiania, Brazil \\ Email: ${ }^{\star d}$ _bartholomeu@yahoo.com.br
}

How to cite this paper: Bartholomeu, D., Montiel, J. M., Couto, G., Bueno, C. H., Garcia, F. H. S., \& Pessotto, F. (2021). Social Skills and Social Acceptance in Different Educational Levels: A Cross-Sectional Study. Psychology, 12, 1886-1899.

https://doi.org/10.4236/psych.2021.1211114

Received: September 15, 2021

Accepted: November 27, 2021

Published: November 30, 2021

Copyright (C) 2021 by author(s) and Scientific Research Publishing Inc. This work is licensed under the Creative Commons Attribution International License (CC BY 4.0).

http://creativecommons.org/licenses/by/4.0/

\begin{abstract}
This research examined whether social ability measures related to acceptance and rejection differ based on varying educational levels. 257 primary school children, 45 high school teenagers, and 126 university students, male and female participated in the study. They completed the Inventory of Social Abilities, the Test of Social Abilities for Children in School Situation and a Sociometric Measure, used to determine the sociometric position each participant occupied within the group, in three situations: hanging out with, playing, and studying with. Results suggest that social skills seem to decrease rejection, instead of enabling social acceptance.
\end{abstract}

\section{Keywords}

Social Skills, Social Acceptance, Educational Level

\section{Introduction}

Group belonging is an essential need for all people (e.g., Baumeister \& Leary, 1995). Given the importance of groups to our survival and our psychological well-being, understanding the structure of groups is of obvious importance. The structure of every group allows each person to occupy a specific position but also has relating to other group members. This core of relations, how a person relates to all the others in his or her group, is referred to as the social atom (Moreno, 1980). It is made up of the sum of a person's interpersonal relationships, which are essential to his/her daily living. Dimitrov and Ebsary (1999) suggested that, when a person joins a group, the others inside it search for cues of acceptance, 
and, at the same time, fear rejection. Those conditions (search for acceptance and avoid group rejection) start a set of individual strategies aiming to understand the group references to a better adjustment. Thus, sociometric status is a product of interactions between individuals' strategies for group interactions and the groups' references and perceptions of those interactions.

The impact of ages and groups norms is an important topic to be addressed in this field of research as social skills change across development as well as social demands. Hence, this research will be conducted to clarify some of these aspects.

Our social worlds are largely defined by how we are accepted or rejected by peers, and this can affect how we succeed or fail in both personal and even academic domains. The way we relate to other people can have a huge impact on our motivation to achieve. Thus, schools and universities must acknowledge the dynamics of relationships to understand how they affect learning and behavior (Bandeira, Rocha, Pires, Del Prete, \& Del Prete, 2006). Peer acceptance works in different ways than other aspects of peer functioning, such as friendship, or participation in social networks. Normally, peer acceptance refers to the degree to which a person is approved or not by group members in the course of a given activity. Thus, someone can be accepted by others without being close friends with them. Interest on developmental meaning of sociometric status began with the relation between childhood experiences (such as parental styles), and social status, as well as relating sociometric status to other developmental features (Bartholomeu, Carvalho, Silva, \& Machado, 2011; Gifford-Smith \& Brownell, 2003; Ollendick, Weinst, Borden, \& Greene, 1992).

Moreno (1972) believed that it was possible to identify the complex structure of a group organization by analyzing the results of the sociometric test. Therefore, sociometry appears as an important tool, for it is not always possible to identify the real configurations assumed by individuals within a group. For example, popular children tend to express a pattern of social information processing that reflects a priority of sustaining positive peer relations, involving a more precise ability in decoding social clues, perception of sympathetic intentions (instead of provocation), creation of strategies of prosocial problem solving and appreciation of relational objectives, instead of instrumental ones (Dodge \& Price, 1994; Nelson \& Crick, 2002). However, the group of popular people is less homogeneous and there are studies suggesting the presence of at least two kinds of popularity, one characterized by social attributes, and another by a mixture of prosocial attitudes combined with aggression and dominance traits (Lease, 1999; Rodkin, Farmer, Pearl, \& Van Acker, 2000). Therefore, sociometric techniques are defined as the mathematical study of group relations and are useful tools for these purposes, as they permit the study of group structures through the estimates of children's acceptance or rejection within a group. However, they are not enough to explain all the situations implied on those attitudes, only being restricted to showing the accepted or rejected ones.

Generally, it is a complicated task to examine the relations between sociome- 
tric status and psychological variables, because considering global constructs categories might lead to wrong results, due to the fact that ways, functions and meanings of behaviors change in different developmental and interactive contexts. People's abilities of identifying the context and developmental changes and adjusting their behavior to them seem to be important predictors of sociometric status (Gifford-Smith \& Brownell, 2003).

For example, Torrente, Capella, and Neal (2014) report the lack of studies examining context differences in the relations between sociometric status and psychological aspects. Other authors explain that the majority of studies focus in behavior problems, instead of positive behaviors, that are more significant to academic success and well-being (Berger \& Rodkin, 2012; Gifford-Smith \& Brownell, 2003). Using the Social Abilities Inventory (IHS), as well as a sociometric measurement, Bartholomeu, Carvalho, Silva, and Machado (2011) studied a group of Physical Education students, relating social abilities with acceptance-rejection. Results showed that, among male participants, acceptance was not related to any social ability, whereas for female participants, it was explained by exposure to strangers. In addition, Bartholomeu, Montiel, and Pessotto (2012) analyzed correlations between social abilities and whether peers accepted others as partners among 16- to 18-year-old teenagers, in two situations, "studying with" and "hanging with". Results revealed that, among male participants, self-assurance in positive emotional expression was significantly related to acceptance and rejection for study; boys who were able to exhibit self-control in aggressive situations (e.g., expressing themselves in socially competent ways) were less rejected as study partners than those who were unable to exhibit self-control. Among female participants, no measures were significantly associated with partner selection.

Research investigating how such factors relates to peers' acceptance and rejection among college and high school students has been thoroughly conducted. However, little to no work has been conducted among children. Thus, we aimed to examine whether social ability measures (e.g., altruism, prosocial behavior) related to acceptance and rejection differ, in different educational levels, allowing us to assemble some insight into how school stages and social behaviors potentially interact to explain how children choose to accept and reject their peers.

\section{Method}

The research was approved by the University Ethics Committee, process number 424-2010.

\subsection{Participants}

Primary school group: 257 children (58\% female, $42 \%$ male), attending 2nd to 4th year primary government schools in São Paulo (Brazil), aged 8 to 11 years $\left(\mathrm{M}_{\mathrm{Age}}=9\right.$ years, $\left.\mathrm{SD}_{\text {Age }}=0.77\right)$, from poor and middle class areas participated in the study. 
High school group: 45 teenagers (56\% female, 44\% male), attending a private school in São Paulo (Brazil), aged 16 to 18 years $\left(\mathrm{M}_{\mathrm{Age}}=16\right.$ years, $\left.\mathrm{SD}_{\text {Age }}=0.61\right)$, participated in the study.

University Students Group: 126 university students (47\% female, 53\% male), attending 4th year of Physical Education course from a private university in São Paulo (Brazil), aged 18 to 35 years $\left(\mathrm{M}_{\text {Age }}=21\right.$ years, $\left.\mathrm{SD}_{\text {Age }}=3.37\right)$, participated in the study.

\subsection{Instruments}

1) Inventory of Social Abilities-IHS-Del-Prette (Del Prette \& Del Prette, 2001).

This measure consists of 38 items related to situations in which individuals may engage in social interactions. Participants were asked to read an assertion about how they might behave in the situation and must mark the frequency of each assertion using a five-point scale, varying from never (1) to always (5), in five dimensions: confrontation with risk, self-assertion, conversation and social resources, self-exposure to strangers, and aggression control. Examples include, "when I am in a group of unknown people, I am naturally comfortable talking to others", "when I am sincerely praised by someone, I say thank you", and "I avoid lectures and presentations to strangers".

2) Test of Social Abilities for Children in School Situation-THAS (Bartholomeu, Silva, \& Montiel, 2012): this measure consists of 23 items responded to on a three-point Likert scale (i.e., never, sometimes, and always) assessing three dimensions: civility and altruism; resourcefulness and self-control in social situations; and assertively with confrontation. Example items include, "if my friends are wrong, I offer to help them”, “if I'm criticized, even if it is just, I feel angry", and "when my friends tease me I join in the fun".

3) Sociometric Measure: this sociometric test, based in Moreno (1972), was used to determine the sociometric position each participant occupied within the group, in situations of "hanging out with", "playing with", and "studying with". The technique is a classic sociometric measure allowing group members to select people they would like to perform some activity with and sorting choices (Bustos, 1979). Therefore, students choice to accept or rejected other classmates' participation in a particular activity is used to determine group structure. Hence, the subjects were asked to choose three students among all of their classmates (within whichever class they were in) with whom they wanted to study. They also had to identify three students with whom they would not want to work or join them in the "studying with" situation. Here, we used the study activity in the schools/college based on previous research that employed the same variables as the reason for forming a group (as emphasized by Horrocks \& Wear, 1953). While in some studies the number of peers participants selected to work with or not to work with was more than three, we chose to limit the selections to three for each category to facilitate data processing and optimize the information collection. Bustos (1979) and Moreno (1972) emphasize that the existence of vari- 
ous human activities and groups justify the adoption of many sociometric criteria, and that the number of people selected in sociometric tests does not affect the test's basic structure. Furthermore, the structure adopted in the current research (i.e., using three options for acceptance and three for rejection) has been used in other studies (e.g., Sisto, Oliveira, Oliveira, Bartholomeu, Oliveira, \& Costa, 2004).

Therefore, each student was asked to select three of their colleagues in the classroom with whom they would like to study and three with whom they did not want to study. For the "acceptance condition", the first person selected to study with received a score of 3 , followed by a score of 2 for the second person, and a score of 1 for the third person. Regarding the "rejection condition", the person they least wanted to study with received a -3 , followed by a -2 for the second person, and a -1 for the third person. These were then collapsed across all student ratings, so that each student in the class had a score assessing the aggregated extent to which they were accepted or rejected by the classroom as a whole; the sum of the rejections produced the rejection score of each student and the sum of the acceptance scores produced the acceptance total score. The sociometric score for each person was established based on the arithmetic sum of each person total acceptance and rejection. The sum of the choices, for example, yielded a continuous score of acceptance for each subject and separately, of rejection for each participant.

\subsection{Procedures}

Instruments were collectively completed in all groups, after parents (in the case of underage children/teens), or the participant signed a letter of consent. In the children's and teenagers group, the researchers read all the questions for each test aloud. Following all the measures listed above, demographic information was collected, and participants were debriefed and thanked for their participation. Adults were assessed at their universities as authorized by course coordinators and teachers. All participants were firstly collected sociometric nominations in both social situations and then assessed by the social skills instruments.

\section{Results}

Descriptive statistics results for high school participants showed poor dispersion in IHD scores, suggesting a low variability around the means. Sociometric measures showed higher dispersion around means, indicating a higher variation of acceptance and rejection to studying with. Skewness and kurtosis coefficients were within acceptable parameters, suggesting that total scores tended to normality. However, acceptance and rejection to studying with measures showed skewness and kurtosis above expected parameters, suggesting asymmetry in distributions, and thus normality cannot be assumed for those measures. 
Among the University students' group, 50\% were neither accepted nor rejected in the studying with situation, and around 65\% were not rejected by anyone in their groups. This is consistent with Horrocks' (1953) proposal that large groups present more number of non-chosen people and less number of leaders (people with a lot of acceptance within the group). In fact, in the studying with situation, only one person was largely accepted (23 acceptances) and only three people received as many as 15 acceptances. Regarding social skills, only expression of positive affection as a factor presented some small degree of asymmetry, violating normality principles.

In the children's group, sociometric measures presented deviations to normality, with a large concentration of rejected children and a small number of acceptances. Concerning social skills, there were children with high scores in all factors, which were evenly distributed for each skill.

We next examined the data along gender lines, as many studies in social skills and social behavior do in their analyses (e.g., Taylor \& Graham, 2007; Zimmer-Gembeck, Geiger, \& Crick, 2005). Firstly, correlations between social skills and acceptance/rejection to studying with measures were separately established by school levels and by gender. Then, statistically significant coefficients of a given behavior were compared with acceptance/rejection to studying with, using the Fisher test. Table 1 and Table 2 show results in the magnitude of associations between social skills and acceptance/rejection to studying with.

Table 1. Correlation coefficients between social skills and acceptance/rejection in different education levels (male participants).

\begin{tabular}{|c|c|c|c|c|}
\hline Factors & Groups & $\begin{array}{l}\text { Acceptance } \\
\text { (Study with) }\end{array}$ & $\begin{array}{c}\text { Rejection } \\
\text { (Study with) }\end{array}$ & $\begin{array}{l}\text { Socio General } \\
\text { (Study with) }\end{array}$ \\
\hline \multirow{3}{*}{$\begin{array}{l}\text { Confrontation with } \\
\text { risk/Assertiveness }\end{array}$} & child & -0.076 & -0.137 & \\
\hline & teenager & -0.061 & 0.054 & 0.09 \\
\hline & adult & 0.156 & -0.116 & -0.047 \\
\hline \multirow{3}{*}{$\begin{array}{l}\text { Expressions of positive } \\
\text { affection/Altruism }\end{array}$} & child & 0.073 & -0.227 & \\
\hline & teenager & $0.553^{*}$ & $-0.445^{\star}$ & $0.503^{*}$ \\
\hline & adult & 0.042 & 0.033 & 0.051 \\
\hline \multirow{3}{*}{$\begin{array}{l}\text { Conversation and Social } \\
\text { Resourcefulness }\end{array}$} & child & -0.075 & 0.001 & \\
\hline & teenager & -0.252 & -0.202 & -0.313 \\
\hline & adult & 0.018 & 0.035 & 0.042 \\
\hline \multirow{2}{*}{$\begin{array}{l}\text { Self-exposure to } \\
\text { strangers or to } \\
\text { new situations }\end{array}$} & $\begin{array}{l}\text { child } \\
\text { teenager }\end{array}$ & -0.174 & -0.388 & -0.346 \\
\hline & adult & 0.090 & -0.053 & -0.011 \\
\hline \multirow{3}{*}{ Self-control of aggression } & child & & & \\
\hline & teenager & 0.214 & $0.507^{\star}$ & $0.516^{*}$ \\
\hline & adult & -0.117 & $0.253^{*}$ & 0.199 \\
\hline
\end{tabular}

*Significant at 0.05 . 
Table 2. Correlation coefficients between social skills and acceptance/rejection in different education levels (female participants).

\begin{tabular}{|c|c|c|c|c|}
\hline Factors & Groups & $\begin{array}{l}\text { Acceptance } \\
\text { (Study with) }\end{array}$ & $\begin{array}{c}\text { Rejection } \\
\text { (Study with) }\end{array}$ & $\begin{array}{l}\text { Socio General } \\
\text { (Study with) }\end{array}$ \\
\hline \multirow{3}{*}{$\begin{array}{l}\text { Confrontation with } \\
\text { risk/Assertiveness }\end{array}$} & child & 0.208 & -0.134 & \\
\hline & teenager & -0.285 & -0.349 & -0.333 \\
\hline & adult & 0.061 & -0.004 & 0.053 \\
\hline \multirow{3}{*}{$\begin{array}{l}\text { Expressions of positive } \\
\text { affection/Altruism }\end{array}$} & child & 0.101 & $-0.246^{*}$ & \\
\hline & teenager & -0.024 & -0.202 & -0.087 \\
\hline & adult & -0.212 & 0.041 & -0.173 \\
\hline \multirow{3}{*}{$\begin{array}{l}\text { Conversation and Social } \\
\text { Resourcefulness }\end{array}$} & child & -0.066 & -0.032 & \\
\hline & teenager & 0.045 & -0.188 & 0.004 \\
\hline & adult & -0.047 & -0.025 & -0.059 \\
\hline \multirow{3}{*}{$\begin{array}{l}\text { Self-esposure to strangers } \\
\text { or to new situations }\end{array}$} & child & & & \\
\hline & teenager & -0.014 & 0.007 & 0.071 \\
\hline & adult & $0.265^{\star}$ & -0.168 & 0.145 \\
\hline \multirow{3}{*}{ Self-control of aggression } & child & & & \\
\hline & teenager & 0.054 & 0 & 0.082 \\
\hline & adult & -0.009 & 0.024 & -0.072 \\
\hline
\end{tabular}

${ }^{\star}$ Significant at 0.05 .

For male participants (see Table 1), expression of positive affection factor and altruism were positively associated with acceptance to studying with, and negatively to rejection to studying with in teenagers; results were different for children and adult groups. Self-control of aggression was associated with rejection in teenagers. In this sense, for male subjects, aggression control is not associated to acceptance, but to rejection in the studying with situation in teenagers, although levels are not maintained in other school periods (university, for example). It is important to note that measures in children did not cover all domains as High School and University did.

For female (see Table 2), expression of positive affection was negatively associated to rejection to studying with, with a higher significant coefficient than the university students' group, as an indication of being an important ability for children and teenagers, but not relevant in university contexts, as to minimize the rejection to studying with.

We next performed a regression analysis, to compare all coefficients in the three groups, conducted following Bruin (2006), Weaver \& Wuensch (2013), and Howell (2013). Social skills variables for each group were created and then each of them was multiplied for the variable that determines the groups in school levels; finally, they were included in the model to explain, firstly acceptance to studying with and then acceptance to studying with (dependent variable). This analysis was also divided by gender, and hierarchically constructed, as social 
skills are supposed to begin earlier in development. Thus, social skills in infancy appear in first level, followed by high school and university, according to psychological development, as it may be observed in Tables 3-6 below.

Table 3. Regression coefficients and significance levels for a model explaining social skills as predictors of social rejection to studying with (male participants).

\begin{tabular}{|c|c|c|c|c|c|c|c|c|}
\hline & \multirow{2}{*}{ Model } & \multicolumn{2}{|c|}{ Unstandardized Coefficients } & \multirow{2}{*}{$\begin{array}{c}\begin{array}{c}\text { Standardized } \\
\text { Coefficients }\end{array} \\
\text { Beta }\end{array}$} & \multirow[t]{2}{*}{$\mathrm{t}$} & \multirow[t]{2}{*}{ Sig. } & \multirow[t]{2}{*}{$\mathrm{F}$} & \multirow[t]{2}{*}{ Sig } \\
\hline & & $\mathrm{B}$ & Std. Error & & & & & \\
\hline \multirow{2}{*}{14} & (Constant) & -0.051 & 0.097 & & -0.524 & 0.601 & & \\
\hline & Self control of agression & -0.335 & 0.166 & -0.162 & 2.017 & 0.045 & 4.06 & 0.045 \\
\hline
\end{tabular}

Table 4. Regression coefficients and significance levels for a model explaining social skills as predictors of social rejection to studying with (female participants).

\begin{tabular}{|c|c|c|c|c|c|c|c|c|}
\hline & \multirow[t]{2}{*}{ Model } & \multicolumn{2}{|c|}{ Unstandardized Coefficients } & \multirow{2}{*}{$\begin{array}{c}\begin{array}{c}\text { Standardized } \\
\text { Coefficients }\end{array} \\
\text { Beta }\end{array}$} & \multirow[t]{2}{*}{$\mathrm{t}$} & \multirow[t]{2}{*}{ Sig. } & \multirow[t]{2}{*}{$\mathrm{F}$} & \multirow[t]{2}{*}{$\operatorname{sig}$} \\
\hline & & $\mathrm{B}$ & Std. Error & & & & & \\
\hline \multirow{7}{*}{9} & (Constant) & -0.031 & 0.064 & & -0.484 & 0.629 & 4.607 & $0.000^{\mathrm{k}}$ \\
\hline & Altruism & 0.698 & 0.270 & 0.501 & 2.581 & 0.011 & & \\
\hline & General & -0.554 & 0.271 & -0.397 & -2.044 & 0.042 & & \\
\hline & Assertiveness Teens & -0.368 & 0.200 & -0.129 & -1.838 & 0.068 & & \\
\hline & Social Resourcefulness Teens & 0.470 & 0.180 & 0.182 & 2.618 & 0.010 & & \\
\hline & Expression of positive emotions & 0.126 & 0.075 & 0.113 & 1.679 & 0.095 & & \\
\hline & Social resources & 0.204 & 0.090 & 0.153 & 2.266 & 0.024 & & \\
\hline
\end{tabular}

Table 5. Regression coefficients and significance levels for a model explaining social skills as predictors of social acceptance to studying with (male participants).

\begin{tabular}{|c|c|c|c|c|c|c|c|c|}
\hline & \multirow[t]{2}{*}{ Model } & \multicolumn{2}{|c|}{ Unstandardized Coefficients } & \multirow{2}{*}{$\begin{array}{c}\begin{array}{c}\text { Standardized } \\
\text { Coefficients }\end{array} \\
\text { Beta }\end{array}$} & \multirow[t]{2}{*}{$\mathrm{t}$} & \multirow[t]{2}{*}{ Sig. } & \multirow[t]{2}{*}{$\mathrm{F}$} & \multirow[t]{2}{*}{ sig } \\
\hline & & $\mathrm{B}$ & Std. Error & & & & & \\
\hline \multirow{2}{*}{14} & (Constant) & -0.086 & 0.078 & & -1.102 & 0.272 & 8.812 & $0.003^{\mathrm{p}}$ \\
\hline & Expression of positive emotions & 0.856 & 0.289 & 0.230 & 2.968 & 0.003 & & \\
\hline
\end{tabular}

Table 6. Regression coefficients and significance levels for a model explaining social skills as predictors of social acceptance to studying with (female participants).

\begin{tabular}{cccccccc}
\hline \multirow{2}{*}{ Model } & \multicolumn{2}{c}{ Unstandardized Coefficients } & $\begin{array}{c}\text { Standardized } \\
\text { Coefficients }\end{array}$ & $\mathrm{t}$ & Sig. & $\mathrm{F}$ & sig \\
\cline { 2 - 7 } & $\mathrm{B}$ & Std. Error & Beta & & & \\
\hline (Constant) & 0.119 & 0.071 & & 1.679 & 0.095 & 3.327 & $0.038^{\circ}$ \\
13 Expression of positive emotions & -0.185 & 0.094 & -0.131 & -1.962 & 0.051 & \\
Conversation & -0.145 & 0.071 & -0.135 & -2.033 & 0.043 & \\
\hline
\end{tabular}


The analysis showed that for male participants, only self-control of aggression in university students explained rejection to studying with, and the increasing of self-control was associated to less rejection to studying with in this level. This relation was the best one associated to rejection to studying with, regardless of school level, meaning that, although diverse social skills are associated to social rejection in other school levels (as shown by correlational analyses), in university those relations seem to be settled with higher magnitude, and aggression self-control in males is a priority (see Table 3 ).

Among female participants, variables associated to rejection to studying with and more significantly comparing social skills and educational levels were altruism (in children), and social resources (teenagers, and less strongly, in university students). Higher regression magnitudes occurred in children, decreasing during the developmental span (see Table 4).

Thus, for males, social skills that are strongly associated with being rejected by peers appear to be developed in adult life, while for females, those social skills strongly related to rejection develop in childhood and decrease with development. The fact that the correlation coefficients between acceptance/rejection to studying with situation and social skills decrease with age among female participants might indicate that other variables are associated with social rejection, as school progresses, such that, for females, social skills are only part of the predictive model. However, for males, the opposite seems to occur; the development of social skills helps in decreasing social rejection in higher educational levels (university) for men but have a smaller effect in primary and high school.

\section{Discussion}

Although the examination of relations between sociometric status and psychological elements has been extensively studied in literature, it is a complicated task. The analysis of global categories of concepts may lead to incorrect conclusions, in part because they depend on other contextual, developmental and individual factors that affect the functions and meanings of behaviors (Gifford-Smith \& Brownell, 2003; Torrente, Capella, \& Neal, 2014).

The discussion will be divided into parts based on studied social situations and gender.

\subsection{Social Situations}

The only variable that explained social acceptance in the male sample was the expression of positive emotions, suggesting that social skills are not related to peer acceptance for males; it is only relevant in high school. Contrary to male participants, social skills decreased peer acceptance to studying with among female participants. Apparently, in studying with situation, abilities of conversation and expression of positive emotions were not favorable variables in university level.

Those results confirm Bartholomeu, Carvalho, Silva, and Machado (2011), and 
Bartholomeu, Montiel, and Pessoto (2012), suggesting that social skills seem to decrease rejection, instead of enabling social acceptance. That happened in female participants, as a larger amount of social skills explained non-rejection within the group, but none was positively associated with acceptance. Women, in fact, present a larger social repertoire compared to men (Taylor \& Graham, 2007; Zimmer-Gembeck, Geiger, \& Crick, 2005) and that may help explain why lower social skills were associated with acceptance and rejection among men, especially in high school and university settings. This suggests that only in those periods do the social skills studied in this research seem to be related to decreased rejection and increased acceptance among peers.

It is interesting to observe that some behaviors, that are not favored at first, are accepted in the course of development. For example, aggressive children who are rejected in preschool are accepted in 4th year primary, especially among boys (Sandstrom \& Coie, 1999). In addition, behavior and personality traits other than social skills are related to acceptance and rejection, particularly in higher school years. The more intricate the relations, the more psychological and behavioral aspects tend to explain social acceptance and rejection (Morais, Otta, \& Scala, 2001).

Some studies suggest that popular children may be divided into two groups those who engage in more prosocial behaviors and those with more aggressive and socially dominant traits (Parkhurst \& Hopmeyer, 1998; Rodkin, Farmer, Pearl, \& Van Acker, 2000). As development progresses, social status and popularity are associated with social dominance, suggesting a link with assertiveness (Lease, 1999). Although associations between prosocial behaviors and peer acceptance were low, other prosocial variables such as conversational skills and emotional expression appeared in increasing acceptance.

Part of the differences in those associations has been credited to the differences in the instruments employed in assessing those constructs. Most studies do not specify acceptance and rejection conditions, whether it is for studying with or for working in classroom activities. At the same time, several use teachers' opinions about the classroom's social groups rather than a true sociometric measure. That variability in measurement may be partially related to the variability in previous findings. Additionally, the instruments used to assess teenagers and University students' social skills are different from the ones used with children, although all consider the same concepts and have a common foundation (George \& Hartman, 1996; Lese, Kennedy, \& Axelrod, 2002; Rodkin, Farmer, Pearl, \& Van Acker, 2000).

\subsection{Gender Differences}

Our results also found gender differences, insofar as girls displayed a larger range of social skills than do boys, seeking more information about social situations, showing prosocial behaviors, as well as having less pressure to preventing emotional expressions than did boys (Berger \& Rodkin, 2012; Rotenberg \& Ensen- 
berg, 1997; Taylor \& Graham, 2007; Torrente, Capella, \& Neal, 2014). This may explain the reason for female participants showing a larger amount of social behaviors in order to minimize rejection and maximize group acceptance in all schools levels.

Maybe boys in primary school have different tools, or other social skills to prevent social rejection, that were not assessed in this study (Berger \& Rodkin, 2012; Gifford-Smith \& Brownell, 2003). A possible explanation is found in Lease (1999), and Rodkin, Farmer, Pearl, and Van Acker (2000) who suggest that more popular boys present a mix of prosocial behaviors as well as aggression and dominance traits. That calls the attention to studying other variables related to social acceptance among peers in different school levels.

\subsection{Final Considerations}

The present study brings contributions in associating social skills with peer acceptance and rejection in studying situations at different school levels and may serve as a guide to develop interventions.

However, there are limitations to be considered. The first one is the difference in number of participants in each school level. In fact, the main objectives were to present some data to emphasize the role of development and social demands on the relations between social skills and social acceptance and even with a small sample this relations have been evidenced. But new studies should address this question with bigger samples. The second is the cross-sectional design of the research. Some studies such as Bierman and Montminy (1993) did not find differences in prosocial and social preference in 1st-to-6th-year primary school children, partly in opposition to the present research. Longitudinal studies are needed to test whether group and context conditions would have similar effects in a given school, as the present research assessed different schools. School environment may produce a context bias, to be controlled in future research (Torrente, Capella, \& Neal, 2014), as well as differences between government and private schools.

Another aspect to be considered is related to the teacher's role in producing social preferences in classroom, as in study oriented classes, children who are the teachers' favorites tend to be more socially accepted by others (Hughes, Luo, Kwok, \& Loyd, 2008; Hughes, Zhang, \& Hill, 2006). Thus, quality of teacher-student relation must be considered and controlled. Controlling for various other personality factors should also be considered, as there are other factors related to social skills and sociometry that might have influenced the results (e.g., Bartholomeu, Nunes, \& Machado, 2010; Bueno, Oliveira, \& Oliveira, 2001; Sisto et al., 2004).

Understanding the factors that relate to how students are included or excluded by their peers at any age is of the utmost importance. Rejection is an incredibly painful experience (e.g., Williams, 2007) and given the relationship between social exclusion and isolation and school violence and self-harm (e.g., 
Anderson, Kaufman, Simon, Barrios, Paulozzi, Ryan et al., 2001; Leary, Kowalski, Smith, \& Phillips, 2003), this research and additional future research seem particularly worthy of note.

\section{Conflicts of Interest}

The authors declare no conflicts of interest regarding the publication of this paper.

\section{References}

Anderson, M., Kaufman, J., Simon, T., Barrios, L., Paulozzi, L., Ryan, R. et al. (2001). School-Associated Violent Deaths in the United States, 1994-1999. Journal of the American Medical Association, 286, 2695-2702. https://doi.org/10.1001/jama.286.21.2695

Bandeira, M., Rocha, S. S., Pires, L. G., Del Prette, Z. A. P., \& Del Prette, A. (2006). Competência acadêmica de crianças do Ensino Fundamental: Características sociodemográficas e relação com habilidades sociais. Interação em Psicologia, 10, 53-62. https://doi.org/10.5380/psi.v10i1.5773

Bartholomeu, D., Nunes, C. H. S. S., \& Machado, A. A. (2010). Traços de personalidade e habilidades sociais em universitários. Psico-USF, 13, 41-50.

https://doi.org/10.1590/S1413-82712008000100006

Bartholomeu, D., Carvalho, L. F., Silva, M. C. R., \& Machado, A. A. (2011). Aceitação e Rejeição entre pares e habilidades sociais em universitários. Estudos de Psicologia (Natal), 16, 155-162. https://doi.org/10.1590/S1413-294X2011000200006

Bartholomeu, D., Montiel, J. M., \& Pessotto, F. (2012). Sociometria e habilidades sociais em estudantes do ensino médio. Estudos Interdisciplinares em Psicologia, 2, 211-228. https://doi.org/10.5433/2236-6407.2011v2n2p211

Bartholomeu, D., Silva, M. C. R., \& Montiel, J. M. (2012). Teste de habilidade social para crianças do ensino fundamental (THAS-C). Laboratório de Psicodiagnóstico e Neurociências Cognitivas. UNISAL.

Baumeister, R. F., \& Leary, M. R. (1995). The Need to Belong: Desire for Interpersonal Attachments as a Fundamental Human Motivation. Psychological Bulletin, 117, 497-529. https://doi.org/10.1037/0033-2909.117.3.497

Berger, C., \& Rodkin, P. C. (2012). Group Influences on Individual Aggression and Prosociality: Early Adolescents Who Change Peer Affiliations (Electronic Version). Social Development, 21, 396-413. https://doi.org/10.1111/j.1467-9507.2011.00628.x

Bierman, K. L., \& Montminy, H. P. (1993). Developmental Issues in Social Skills Assessment and Intervention with Children and Adolescents. Behavior Modification, 17, 229-254. https://doi.org/10.1177/01454455930173002

Bruin, J. (2006). Newtest: Command to Compute New Test. UCLA: Academic Technology Services, Statistical Consulting Group.

Bueno, J. M. H., Oliveira, S. M. S. S., \& Oliveira, J. C. S. (2001). Um Estudo correlacional entre habilidades sociais e traços de personalidade com universitários. Psico-USF, 6, 31-38. https://doi.org/10.1590/S1413-82712001000100005

Bustos, D. M. (1979). O teste sociométrico. Editora Brasiliense.

Del Prette, Z. A. P., \& Del Prette, A. (2001). Inventário de Habilidades Sociais (HIS-DelPrette): Manual de aplicação, apuração e interpretação. Casa do Psicólogo.

Dimitrov, V., \& Ebsary, R. (1999). Autopoiese intrapessoal. IECPS. 
Dodge, K., \& Price, J. M. (1994). On the Relation between Social Information Processing and Socially Competent Behavior in Early School-Aged Children. Child Development, 65, 1385-1397. https://doi.org/10.2307/1131505

George, T. P., \& Hartmann, D. P. (1996) Friendship Networks of Unpopular, Average, and Popular Children. Child Development, 67, 2301-2316. https://doi.org/10.2307/1131624

Gifford-Smith, M. E., \& Brownell, C. A. (2003). Childhood Peer Relationships: Social Acceptance, Friendships, and Peer Networks. Journal of School Psychology, 41, 235-284. https://doi.org/10.1016/S0022-4405(03)00048-7

Horrocks, J. E., \& Wear, B. A. (1953). An Analysis of Interpersonal Choice Relationships of College Students. Journal of Social Psychology, 38, 87-98. https://doi.org/10.1080/00224545.1953.9711439

Howell, D. C. (2013). Statistical Methods for Psychology. Cengage Wadsworth.

Hughes, J. N., Luo, W., Kwok, O., \& Loyd, L. (2008). Teacher-Student Support, Effortful Engagement, and Achievement: A Three-Year Longitudinal Study. Journal of Educational Psychology, 100, 1-14. https://doi.org/10.1037/0022-0663.100.1.1

Hughes, J., Zhang, D., \& Hill, C. (2006). Peer Assessments of Normative and Individual Teacher-Student Support Predict Social Acceptance and Engagement among Low Achieving Children. Journal of School Psychology, 43, 447-463.

https://doi.org/10.1016/j.jsp.2005.10.002

Leary, M. R., Kowalski, R. M., Smith, L., \& Phillips, S. (2003). Teasing, Rejection, and Violence: Case Studies of the School Shootings. Aggressive Behavior, 29, 202-214.

https://doi.org/10.1002/ab.10061

Lease, S. H. (1999). Occupational Role Stressors, Coping, Support, and Hardiness as Predictors of Strain in Academic Faculty: An Emphasis on New and Femanel Faculty. Research in Higher Education, 40, 285-307. https://doi.org/10.1023/A:1018747000082

Lese, A. M., Kennedy, C. A. \& Axelrod, J. L. (2002). Children's Social Constructions of Popularity. Social Development, 11, 87-109. https://doi.org/10.1111/1467-9507.00188

Morais, M. L. S., Otta, E., \& Scala, C. T. (2001). Status sociométrico e avaliação de características comportamentais: um estudo de competência social em pré-escolares. Psicologia: Reflexão e Crítica, 14, 119-131. https://doi.org/10.1590/S0102-79722001000100010

Moreno, J. L. (1972). Fundamentos de la sociometria. Buenos Aires.

Moreno, J. L. (1980). Psychodrama. Beacon House.

Nelson, D. A., \& Crick, N. R. (2002). Parental Psychological Control: Implications for Childhood Physical and Relational Aggression. In B. K. Barber (Ed.), Intrusive Parenting: How Psychological Control Affects Children and Adolescents (pp. 161-189). American Psychological Association. https://doi.org/10.1037/10422-006

Ollendick, T. H., Weist, M. D., Borden, M. C., \& Greene, R. W. (1992). Sociometric Status and Academic, Behavioral, and Psychological Adjustment: A Five-Year Longitudinal Study. Journal of Consulting \& Clinical Psychology, 60, 80-87. https://doi.org/10.1037/0022-006X.60.1.80

Parkhurst, J. T., \& Hopmeyer, A. (1998). Sociometric Popularity and Peer-Perceived Popularity Two Distinct Dimensions of Peer Status. The Journal of Early Adolescence, 18, 125-144. https://doi.org/10.1177/0272431698018002001

Rodkin, P. C., Farmer, T. W., Pearl, R., \& Van Acker, R. (2000). Heterogeneity of Popular 
Boys: Antisocial and Prosocial Configurations. Developmental Psychology, 36, 14-24. https://doi.org/10.1037/0012-1649.36.1.14

Rotenberg, K. J. \& Eisenberg, N. (1997). Developmental Differences in the Understanding of and Reaction to Others' Inhibition of Emotional Expression. Developmental Psychology, 33, 526-537. https://doi.org/10.1037/0012-1649.33.3.526

Sandstrom, M. J., \& Coie, J. D. (1999). A Developmental Perspective on Peer Rejection: Mechanisms of Stability and Change. Child Development, 70, 955-966. https://doi.org/10.1111/1467-8624.00069

Sisto, F. F., Oliveira, S. M. S. S., Oliveira, K. L., Bartholomeu, D., Oliveira, J. C. S., \& Costa, O. R. S. (2004). Escala de traços de personalidade para crianças e aceitação social entre pares. Interação, 8, 15-24. https://doi.org/10.5380/psi.v8i1.3235

Taylor, A. Z., \& Graham, S. (2007). An Examination of the Relationship between Achievement Values and Perceptions Barriers among Low SES African American and Latino Students. Journal of Education Psychology, 99, 52-64.

https://doi.org/10.1037/0022-0663.99.1.52

Torrente, C. E., Capella, E. \& Neal, J. W. (2014).Children's Positive School Behaviors and Social Preference in Urban Elementary Classrooms. Journal of Community Psychology, 42, 143-161. https://doi.org/10.1002/jcop.21599

Weaver, B., \& Wuensch, K. L. (2013). SPSS and SAS Programs for Comparing Pearson Correlations and OLS Regression Coefficients. Behavior Research Methods, 45, 880-895. https://doi.org/10.3758/s13428-012-0289-7

Williams, K. D. (2007). Ostracism. Annual Review of Psychology, 58, 425-452. https://doi.org/10.1146/annurev.psych.58.110405.085641

Zimmer-Gembeck, M. J., Geiger, T. A., \& Crick, N. R. (2005). Relational and Physical Aggression, Prosocial Behavior, and Peer Relations: Gender Moderation and Bidirectional Associations. The Journal of Early Adolescence, 25, 421-424.

https://doi.org/10.1177/0272431605279841 